\title{
A Comparative Study on Teaching Writing Through 3D Virtual Reality Video and 2D Video as Teaching Media
}

\author{
Moris Virgiawan, Nunuk Suryani,and Leo Agung Sutimin \\ Faculty of Education and Teacher Training, Universitas Sebelas Maret, Surakarta, Indonesia \\ Morisv75@gmail.com
}

\begin{abstract}
This article presents the result of the research study aimed at finding out: (1) whether there is any significant difference in writing achievement between the students taught using 3D Virtual Reality video and those taught using 2D video; and (2) whether the students taught using 3D Virtual Reality video have higher writing achievement than those taught using $2 \mathrm{D}$ video. The research method used in this study is a quasi-experimental research design. This research was conducted at a privat Senior High School in Surakarta in the academic year of 2019/2020. This research used cluster sampling that involve two clasess of eleventh grade students. The samples are class XI IPA 1 as the experimental class which consists of 30 students and class XI IPA 2 as the control class which consists of 30 students. The research instrument used to collect the data in this study is test. The data were analysed by using t-test formula. The computation of the $\mathrm{t}$-test shows that $\mathrm{t}$ observation $\left(\mathrm{t}_{\mathrm{o}}\right)=2.1028$ is higher than $\mathrm{t}$ table $(58,0.05)=$ 2.0017. Therefore, it can be concluded that there is a significant difference in writing achievement between students taught using 2D video and those taught using 3D Virtual Reality video. The mean score of the experimental group improved from 67.56 to 76.55 , while the mean of the score of control group improved from 67.26 to 73.25 . The improvement of the experimental group is higher than the control group. It can be concluded that the students taught using 3D Virtual Reality video have higher writing achievement than those taught using 2D video.
\end{abstract}

Keywords: 2D video, 3D Virtual Reality video, writing skill.

\section{INTRODUCTION}

In learning English, there are four language skills that should be mastered namely; listening, speaking, reading, and writing. Listening and reading are the receptive skills in which the language users require to receive spoken and written language. On the other hand, speaking and writing are productive skills in which the language users require to produce language, both spoken and written.

As a productive skill, speaking and writing are basically different. While we speak, we use a variety of prosodic features such as pitch, loudness, speed, rhythm, pauses and so on that help us to get the feedback from listeners but this does not happen in case of writing where the context is created through the words alone and without the direct interaction between the writer and the reader[1]. Writing is an integral part of communication when the other person is not right there in front of us, listening to our words and looking at our gestures and facial expression[2]. In other words, writing is different from speaking in term of 
communication context. Speaking is intended for face to face communication among the speaker and the listener directly, while writing is used by the writers to express and communicate their ideas to the readers who are actually separated by both time and space distances. Therefore, it requires clearer and more comprehensive message to avoidmisinterpretation from the reader.

In general, writing is an act of transferring ideas into written form. Writing is the process of thinking to invent ideas, thinking about how to express into good writing, and arranging the ideas into statementand paragraph clearly[3]. Moreover, writing defines as a complex activity[4]. It becomes a complex activity because it relates to some basic knowledge like organization, vocabulary mastery, grammar,mechanics, and also involves the content.From those statements, it can be concluded that writing is a complex process of expressing ideas from the writers' thought intowritten form by considering organization, vocabulary mastery, grammar,mechanics, and also the content to arrange the ideas into understandable statementand paragraph.

Regarding into its complexcity, writing skill is often perceived as the most difficult skill to be mastered because it requires many aspects of language in its production such as organization, content, language use, mechanics and vocabulary. Moreover, some of students are not confident enough to write. They lose their enthusiasm. There are some reasons for students not to write, perhaps students have never written much in first language(s) or they do not have anything to say and cannot come up with ideas[5]. Therefore, the teacher should stimulate the student to make them come up with ideas and start their writing.

Video can be used as a trigger to help teacher in stimulating the students before writing.Video can give a strong effect on the mind and senses [6]. Moreover, bywatching video, students having a chance to generate their ideas and get more inspiration forwriting.Video today is often used for demonstration and evaluation, but we believe that a more productive approach is to use video to support teachers' ability to notice and interpret classroom interactions [7].However, video is a moving image that can display a situation, whatever its shape, the video can only display two-dimensional images only. Users cannot experience the exact conditions. This becomes the weak point of a video, so video still cannot make the message or material to its full potential.

Another media that can be uesd by the teacher to stimulate the student before wiring is $3 \mathrm{D}$ Virtual Reality video. Virtual reality or commonly called VR is a three-dimensional video technology that allows users to interact with existing environments in the virtual world that are simulated by a computer, so that users feel they are in that environment. Virtual Reality (VR) is a computer-based technology that combines special input and output devices so that users can interact deeply with virtual environments as if they were in the real world [8]. The goal of using 3D Virtual Reality video is to achieve a strong sense of being present in a virtual environment that seems very real [9]. The three-dimensional experiences are designed as supplement for teacher's traditional lesson plan, by allowing students to see objects situated in their real life[10]. By using 3D Virtual Reality video teachers can take their students anywhere around the world without leaving the classroom, thus give more memorable experience, so as to provide inspiration forwriting.Additionally, it can provide an informal learning context which can support the learning gains acquired in classroom setting. Moreover, it presents both joyful and exciting course moments by simulating impossible and dangerous events in the classroom [11]. However, 3DVirtual Reality video might bring about a number of physical discomfort due to the use of Virtual Reality headset[12]. Moreover, when such students wear these headsets their vision and hearing could be restricted to only the virtual environment so 
that managing the classroom teaching through virtual reality could be a problem.So, the teachers should apply appropriate teaching method which is suitable with the media.

\section{METHOD}

The researcher decided to use quasi-experimental research because it enables a researcher to identify causal relationships because it allows the researcher to observe, under controlled conditions, the effects of systematically changing one or more variables [13]. This research was conducted at the eleventh grade of SMA Batik 2 Surakarta from 22 August to 24 September 2019, in the academic year of 2019/2020. The two classes used as the sample were chosen randomly by the researcher from nine classes of eleventh grade in SMA Batik 2 Surakarta. The two classes were class XI IPA 3 which consists of 30 students as experimental group who were taught using Interactive Writing and XI IPA 4 which consist of 30 students as control group who were taught using Guided Writing.

In this research, the researcher conducted the try-out test in which the result was analyzed in terms of readability for the writing test instruction. It is tried out in one class that is not included in the research sample but at the same grade in the school. The researcher chose class XI IPA 1 which consists of 34 students to do the try-out test. It is necessary since there have been some cases in which students failed to do the test because they do not understand the given instruction.

Experimental and control groups were given pre-test on writing of Recount text. After that, experimental group was taught by using 3D Virtual Reality video and control group was taught by using 2D video as teaching media. The last, the experimental and control groups were given post-test on writing of Recount text. Post-test was conducted to compare the result of the two groups after they got different types of video as teaching media.

Writing tests, as the research instrument, were used by the researcher to measure the students' writing achievement in order to collect the data. The data which were analyzed are pre-test and post-test scores of experimental group and control group. The data were compared using t-test formula to prove whether there is any significant difference between the two groups in writing achievement, and to find which media is more effective to teach writing.

\section{RESULT AND DISCUSSION}

The aim of the research is to find out: (1) whether there is any significant difference or not in writing achievement of the student taught using 3D Virtual Reality video and those taught using 2D video; and (2) whether which group has a better result in writing. The data description of each group is presented as follows:

Score of Experimental Group

Table 1: The frequency distribution of experimental group pre-test scores

\begin{tabular}{lcclll}
$\begin{array}{l}\text { Class } \\
\text { Limits }\end{array}$ & $\begin{array}{l}\text { Class } \\
\text { Boundaries }\end{array}$ & Midpoint & Tally & Frequency & Percentage \\
\hline $53-56$ & $52.5-56.5$ & 54.5 & I & 1 & 3.33 \\
\hline $57-60$ & $56.5-60.5$ & 58.5 & IIII & 4 & 13.33 \\
\hline $61-64$ & $60.5-64.5$ & 62.5 & III & 3 & 10.00 \\
\hline $65-68$ & $64.5-68.5$ & 66.5 & IIIII IIIII & 10 & 33.33 \\
\hline $69-72$ & $68.5-72.5$ & 70.5 & III & 3 & 10.00 \\
\hline $73-76$ & $72.5-76.5$ & 74.5 & IIIII III & 8 & 26.67 \\
\hline $77-80$ & $76.5-80.5$ & 78.5 & I & 1 & 3.33 \\
\hline
\end{tabular}




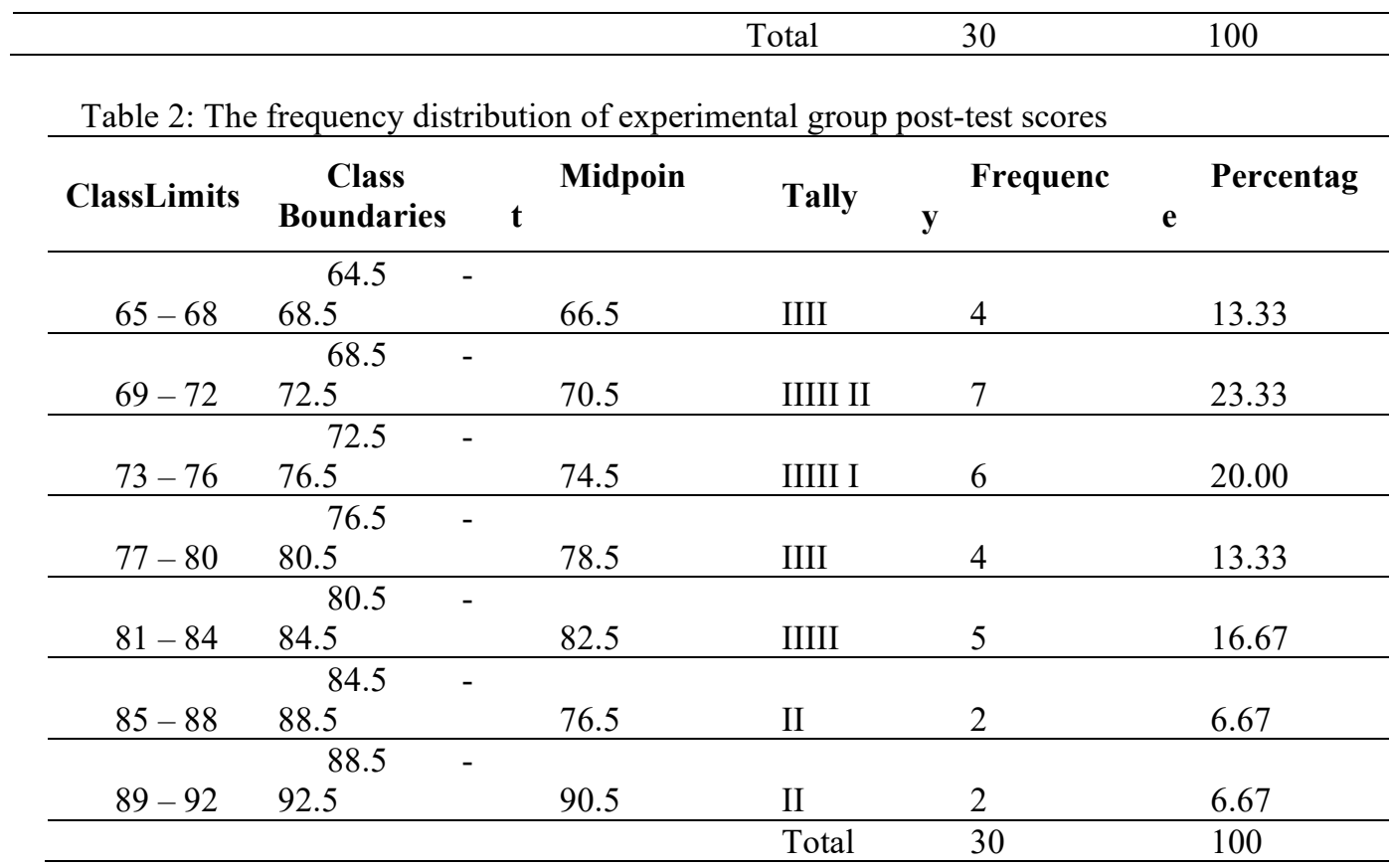

The highest score of pre-test of experimental group is 77 while the highest score of posttest of experimental group is 91, so the difference of pre-test and post-test highest scores of experimental group is 14 . The lowest score of pre-test of experimental group is 53 while the lowest score of post-test of experimental group is 65, so the difference of pre-test and post-test lowest score of experimental group is 12 . The mean score of pre-test of experimental group is 67.56 while the mean score of post-test of experimental group is 76.55 , so the difference of pre-test and post-test mean scores of experimental group is 8.99 .

\section{Score of Control Group}

Table 3: The frequency distribution of control group pre-test scores

\begin{tabular}{|c|c|c|}
\hline Class & Class & Midpoint \\
\hline
\end{tabular}

\begin{tabular}{llllll}
\hline $54-57$ & $53.5-57.5$ & 55.5 & II & 2 & 6.67 \\
\hline $58-61$ & $57.5-61.5$ & 59.5 & III & 3 & 10.00 \\
\hline $62-65$ & $61.5-65.5$ & 63.5 & II & 2 & 6.67 \\
\hline $66-69$ & $66.5-69.5$ & 67.5 & IIIII IIIII & 10 & 33.33 \\
\hline $70-73$ & $69.5-73.5$ & 71.5 & IIIII I & 6 & 20.00 \\
\hline $74-77$ & $73.5-77.5$ & 75.5 & IIII & 4 & 13.33 \\
\hline $78-81$ & $77.5-81.5$ & 79.5 & III & 3 & 10.00 \\
\hline & & & Total & 30 & 100 \\
\hline
\end{tabular}


Table 4: The frequency distribution of control group post-test scores

\begin{tabular}{llllll}
$\begin{array}{l}\text { Class } \\
\text { Limits }\end{array}$ & $\begin{array}{c}\text { Class } \\
\text { Boundaries }\end{array}$ & Midpoint & Tally & $\begin{array}{c}\text { Freque } \\
\text { ncy }\end{array}$ & Percentage \\
\hline $62-65$ & $61.5-65.5$ & 63.5 & II & 2 & 6.67 \\
\hline $66-69$ & $65.5-69.5$ & 67.5 & IIIII & 5 & 16.67 \\
\hline $70-73$ & $69.5-73.5$ & 71.5 & IIIII III & 8 & 26.67 \\
\hline $74-77$ & $73.5-77.5$ & 75.5 & I & IIIII IIIII & \\
\hline $78-81$ & $77.5-81.5$ & 79.5 & II & 2 & 36.67 \\
\hline $82-85$ & $81.5-85.5$ & 83.5 & I & 1 & 6.67 \\
\hline $86-89$ & $86.5-89.5$ & 87.5 & I & 1 & 3.33 \\
\hline & & & Total & 30 & 100 \\
\hline
\end{tabular}

The highest score of pre-test of control group is 79 while the highest score of post-test of control group is 86 , so the difference of pre-test and post-test highest score of control group is 7. The lowest score of pre-test of control group is 54 while the lowest score of post-test of control group is 62, so difference of pre-test and post-test lowest score of control group is 8 . The mean score of pre-test of control group is 67.56 while the mean score of post-test of control group is 73.25 , so the difference of pre-test and post-test mean scores of control group is 5.69 .

\section{Normality and Homogeneity of Pre-test Experimental and Control Groups}

The normality test used in this research is Lilliefors testing at the level of significance of $0.05(\alpha=0.05)$, while the homogeneity testing used Bartlet formula at the level of significance of $0.05(\alpha=0.05)$. The computation results of the normality test of pre-test for experimental and control groups are both experimental group and control group are in normal distribution. In the data of experimental group, it can be seen that Lo is 0.043 . It is then consulted with L table for $\mathrm{n}=30$ at the level of significance of $0.05=0.159$. It can be concluded that the data of experimental group are in normal distribution because the value of Lo is lower than Lt (Lo < Lt).Meanwhile, the data of control group shows that Lo is 0.017 . It is then consulted with L table for $n=30$ at the level of significance of $0.05=0.159$. It can be concluded that the data of control group are in normal distribution because the value of Lo is lower than $\mathrm{Lt}(\mathrm{Lo}<\mathrm{Lt})$.

From the computation of homogeneity test of pre-test, it can be seen that $\chi 02=0.021$ is lower than $\chi^{\mathrm{t} 2}=3.841$ or $\chi_{0} 2<\chi^{\mathrm{t} 2}$. It can be concluded that the data are homogeneous because $\chi_{0} 2$ is lower than $\chi^{\mathrm{t} 2}$. 


\section{Normality and Homogeneity of Post-test Experimental and Control Groups}

From the computation of the normality test of post-test for experimental and control groups, it can be seen that the data of both experimental group and control group are in normal distribution. In the data of experimental group, it can be seen that Lo is 0.011 . It is then consulted with $\mathrm{L}$ table for $\mathrm{n}=30$ at the level of significance of $0.05=0.159$. It can be concluded that the data of experimental group are in normal distribution because the value of Lo is lower than $\mathrm{Lt}(\mathrm{Lo}<\mathrm{Lt})$. Meanwhile, the data of control group show that Lo is 0.030 . It is then consulted with $\mathrm{L}$ table for $\mathrm{n}=30$ at the level of significance of $0.05=0.159$. It can be concluded that the data of control group are in normal distribution because the value of Lo is lower than $\mathrm{Lt}(\mathrm{Lo}<\mathrm{Lt})$.

From the computation of homogeneity test of post-test, it can be seen that $\chi 02=2.320$ is lower than $\chi^{\mathrm{t} 2}=3.841$ or $\chi 02<\chi \mathrm{t} 2$. It can be concluded that the data are homogeneous because $\chi_{0} 2$ is lower than $\chi \mathrm{t} 2$.

\section{Hypothesis Testing}

The researcher tested the null hypothesis $\left(\mathrm{H}_{\mathrm{o}}\right)$ of the research that there is no significant difference in writing achievement between students taught using 3D Virtual Reality video and those taught using 2D video as teaching media. Statistically, the hypothesis can be formulated as $\mathrm{H}_{0}=\mu 1=\mu 2$.

The alternative hypothesis $\left(\mathrm{H}_{\mathrm{a}}\right)$ of this research is that there is a significant difference in writing achievement between the taught using 3D Virtual Reality video and those taught using $2 \mathrm{D}$ video as teaching media. Statistically, the hypothesis can be formulated as $\mathrm{H}_{\mathrm{a}}=\mu 1 \neq \mu 2$.

It is known that if $t_{0}$ ( $\left.t_{\text {observation }}\right)$ is lower than $t_{t}\left(t_{\text {table }}\right), H_{0}$ is accepted. On the contrary if $t_{o}$ $\left(t_{\text {observation }}\right)$ is higher than $t_{t}\left(t_{\text {table }}\right)$ or $t_{0}>t_{t}, H_{o}$ is rejected.

The result of $t$ computation shows that $t_{0}\left(t_{\text {observation }}\right)$ is 2.1028 while the $t_{t}\left(t_{\text {table }}\right)$ for the degree of freedom 58 and the level of significance $\alpha=0.05$ is 2.0017 so, $t_{0}$ is higher than $\mathrm{t}_{\mathrm{t}}\left(\mathrm{t}_{\mathrm{table}}\right)$. It means that $\mathrm{H}_{\mathrm{o}}$ is rejected. Then it can be concluded that there is a significant difference in writing achievement between students taught using 3D Virtual Reality video and those taught using $2 \mathrm{D}$ video as teaching media.

The second hypothesis of this research is that the students taught using 3D Virtual Reality video have higher writing achievement than those taught using2D video. In order to test the second hypothesis, the writer compares the gain between pre-tests and post-test of the two groups. The mean score of the experimental group improved from 67.56 to 76.55 , while the mean of the score of control group improved from 67.26 to 73.25. The improvement of the experimental group is higher than the control group. It can be concluded that the students taught using 3D Virtual Reality video have higher writing achievement than those taught using2D video.

The result of the research shows that there is a significant difference in writing achievement between the students whom taught using 3D Virtual Reality video and the students taught using 2D video.The use of 3D Virtual Reality attracted more attention from the students with its content. The students taught using 3D Virtual Reality video have higher writing achievement than those taught using2D video.The students presented positive opinions towards the use of 3D Virtual Reality video in writing class. The students thought that 3D Virtual Reality video was promising and motivating. A majority of the students found 3D Virtual Reality video enjoyable and effective as it could present a real-like learning environment and created a feeling of involvement. Especially, some features of VR technologies such as amusement, ease of use, user friendly interface and portability provided positive outcomes among learners. These findings confirmed previous related research which 
especially emphasized the feeling of reality and involvement 3D Virtual Reality video provided [14] [15].

\section{CONCLUSION}

Based on the result of the research, the findings are as: (1) There is a significant difference in writing achievement between the students whom taught using 3D Virtual Reality video and the students taught using 2D video.; and (2) The students taught using 3D Virtual Reality video have higher writing achievement than those taught using2D video.

\section{REFERENCES}

[1]. Bachani, M. 2004. Teaching Wriitng. 1-4. Retrived on August 22, 2019.waymadedu.orgStudentSupportTeaching\%20Writing.pdf.

[2]. Raimes, A. 1983. Techniques in Teaching Writing. New York: Oxford University Press.

[3]. Nunan, D. 2003. Practical English Language Teaching. Singapore: Mc Graw Hill

[4]. Harris, J. 1993. Introducing Writing. London: Penguin English.

[5]. Harmer, J. 2007. The Practice of English Language Teaching. London: Longman

[6]. Berk, Ronald A. (2009)Multimedia Teaching with Video Clips: TV,Movies, YouTube, and mtv in the College Classroom. International Journal of Technology in Teaching and Learning, 5(1), 1-21.

[7]. Sherin, M. G., Linsenmeier, K. A., \& van Es, E. A. (2009)Issues in the design of video clubs: selecting video clips for teacher learning. Journal of TeacherEducation, 60(3), 213e230.

[8]. Chandel, Deepak \& Chauhan, Akshit. (2014)Virtual Reality, International Journal of Science and Research, Vol. 13, no. 10, ISSN (Online) : 2319-7064

[9]. Linowes, J. (2015)Unity Virtual Reality Projects. Birmingham: Packt Publishing Ltd.

[10]. Horn, Michael B. (2017). Virtual Reality Disruption. ProQuest.16, (4), 1 - 4

[11]. Williams-Bell, F. M., Kapralos, B., Hogue, A., Murphy, B. M., \& Weckman, E. J. (2015). Using serious games and virtual simulation for training in the fire service: a review. Fire Technology, 51(3), 553-584.

[12]. Yildirim, G. (2017). The Users'views on Different Types of Instructional Materials Provided in Virtual Reality Technologies. European Journal of Education Studies, 3(11). 150-171.

[13]. Johnson, Burke., Christensen, Larry. (2012). Educational Research: Quantitative, Qualitative, and Mixed Approaches (4th ed.). California: SAGE publications, inc.

[14]. Dong, X. (2016, July). An overall solution of Virtual Reality classroom. In Service Operations and Logistics, and Informatics (SOLI), 2016 IEEE International Conference on (pp. 119-123). IEEE.

[15]. K. Saddhono, A. Hasibuan, and M. I. Bakhtiar, "Facebook as A Learning Media in TISOL (Teaching Indonesian to Speakers of Other Languages) Learning to Support The Independency of Foreign Students in Indonesia," in Journal of Physics: Conference Series, 2019, vol. 1254, no. 1, p. 12061. 